\title{
INTRODUCTION
}

\section{The Enlightenment and modernity}

\section{The rationale of this book}

In historical studies and indeed most fields of the humanities, the terms modernity and Enlightenment are so frequently linked that either term almost automatically evokes the other. It has become an accepted commonplace, part of the historical canon, that modernity began in the Enlightenment. This begs the obvious but yet problematic question: what was the general character of the intellectual phenomenon we term the Enlightenment?

Since the end of the 1960 and 1970s, Enlightenment studies has, albeit rather slowly and unevenly, moved from a rather narrow preoccupation with a few leading intellectuals, to an acceptance that the Enlightenment was in fact a much broader phenomenon. It is now increasingly recognized that the Enlightenment was as diverse in its protagonists as it was geographically and chronologically disparate. Neither was there unity within the Enlightenment on perhaps the central plank of Enlightenment doctrine, the role of reason in the future of civilization. From the mid eighteenth century we see - especially in France and England in the work of Jean Jacques Rousseau and David Hume - a growing rejection of the simple panacea of reason in favour of the equal recognition of the role of the 'passions' in human conduct. This growing rejection of the rather restrictive notion of reason as the fundamental attribute of the human mind also coincided rather paradoxically with what historians have termed the High Enlightenment, but is more aptly known in literary studies as the Age of Sensibility. It is, therefore, not without difficulty that reliance on reason can be cited as an easy key to investigating the broad intellectual manifestation of the years c. 1690-1790 that we have termed the Enlightenment. 


\section{The Enlightenment and religion}

That Enlightenment protagonists were secular in their outlook has also been part of the Enlightenment studies canon. Until the 1970s the characterization of the Enlightenment was most usually that of reason against religion. Since then many academics have preferred the formula reason versus the Church, recognizing that most of the enlightened still retained a belief in God, even if they were hostile to the Church. Belief in an original Creator was part of the deistic view held by some enlightened writers who thought that God had not intervened in worldly affairs since Creation, so rendering the Church's claim to mediation between divinity and humanity fraudulent. For such thinkers, evidence for God and a rational or 'natural religion' lay in the qualities (especially reason and conscience) of an unchanging human nature and the frame of nature itself. The understanding that there was a deist movement (sometimes termed freethinking movement) of some size in Europe has remained the orthodoxy in Enlightenment studies, yet there is no evidence to support this claim. Evidence for the existence of organized deism has not so far been adduced, and evidence for the existence of individual deists indicates the existence of relatively few individuals spread across one hundred years of European history.

It seems, then, that the revision of the character of religion in the Enlightenment was not as thoroughgoing as it might have been, and the traditional linkage of modernity and Enlightenment - in the form of the secularizing deist movement - has continued to be propagated by some and still acknowledged by others. It is not the intention of this book, however, to speculate on the origins of modernity, for, after all, why do the origins of modernity have to be predominantly intellectual? It is equally plausible to suggest other categories of explanation, including that of the broad impact of the Industrial Revolution, which certainly had long-term intellectual consequences when its many powerful protagonists sought to extol its virtues and minimize and justify its less attractive aspects.

Outside of traditional Enlightenment studies there also exists strong support for the Enlightenment-modernity thesis in the form of the so-called postmodernity theory. Apparently (although very few seemed to notice it at the time), modernity gave way to postmodernity in the early 1970s. Without citing any more than the most vague evidence, postmodernists have repeatedly asserted that the secularizing, reason-orientated Enlightenment is the one and only origin of modernity. For postmodernists, modernity is damned 


\section{The Enlightenment and modernity}

because it supposedly placed unfounded reliance on reason as the arbiter of human conduct. Thus reason, Enlightenment and modernity become one. They argue (and here they have a point) that the modern project was a costly failure, bringing not the sweet dreams of reason, but war, famine, disease and ecological disaster.

It is true that postmodernism has been responsible for a renewed interest in the philosophy of history, mostly because it asserts that the past is irretrievably gone and our self-interested attempts at reconstructing it are, by their nature, consequently doomed to failure. The great meta-historical narratives (great schemes of history) of modernity were all pie-in-the-sky, the postmodernists argue, and thus postmodernism is typified, they claim, by an incredulity toward meta-narratives (no longer believing in the promises of modernity). The problem, however, is that when postmodern thinkers characterize the nature and origins of modernity, they are still trying to sell a meta-narrative, a grand scheme of history based on their own analysis of modernity and its origins. The pseudo-historical product it wishes to revamp and sell is that older outlook of Enlightenment studies, in which the Enlightenment is seen as a more or less homogenous phenomenon, led by a substantial movement of deistic radicals guided solely by the false prophet of reason.

Of course postmodernists are correct to point out that the writing of history is never neutral and that this fact must be borne in mind by all those interested in historical questions - just as postmodernists themselves have an interest in a certain analysis of the nature, origins and consequences of modernity. While postmodernists wish to condemn both modernity and its supposed Enlightenment origins, modern historians have touted the Enlightenment as a source of modern progressive ideals such as religious toleration, hostility to superstition and a reverence for knowledge. Indeed, modern historians have repeatedly sought for anything in the eighteenth century that resembled the modern secular outlook, and then, in order to ensure that the evolution of progress was incontrovertibly charted, even sought to chart the proto-modern 'precursors' of the Enlightenment. Some rethinking, therefore, is necessary. In essence, the available evidence has not validated the project of linking what has traditionally been understood as the Enlightenment to modernity. Rethinking does not mean freedom from bias - after all, my views are my own - but it does mean that a more frank attitude towards the nature and problems inherent 


\section{The Enlightenment and religion}

within the historical record is needed and commonplace research assumptions need to be re-examined.

Rarely do the philosophy of history and historical research meet, yet it is only by raising basic but tricky practical and theoretical questions relating to the nature of the historical record that historians can attempt to rethink our understanding of the Enlightenment. It is difficult to overstate the need for a fresh look at the historical record because there is clear evidence to indicate that the protagonists of the Enlightenment also wished to be remembered as 'new thinkers' unsullied with the intellectual baggage of the past. They thus propagandized that which was new or radical in that century, and usually failed to inform us of events, trends and influences from other less radical, traditional sources. There is little evidence that in the achievement of religious toleration - the bedrock of any secularization programme - deistic radicals played any fundamental role. Yet their rhetoric would have us believe just that. On the contrary, there is evidence to indicate that religious toleration began to assert itself as an idea and a practical reality at the grassroots level of eighteenth-century society and that the enlightened responded to public opinion rather than created it. Fundamental social and politico-religious processes have thus been overlooked by historians rather too concerned to relate their present to the past, forging intellectual time-lines and traditions where none really existed.

The following series of discussions represents an attempt to review some of the causes and contexts of religious change in Enlightenment Italy, France and England. Although to a degree different from each other in content and objective, the aim of the case studies is to illustrate how the notion that the Enlightenment founded 'modernity' has led to significant distortions in our understanding of religious and intellectual change. I wish to assert the fundamental role of public opinion in pressure for religious change, but also in the creation of enduring myths such as that of the deist movement. At times, if they did not wish to appear to be lagging behind developments, the philosophes (protagonists of enlightened ideals) were forced to claim broad changes as their own particular victories. If the philosophes cannot be credited with as much as has been traditionally claimed, and other, broader agencies can be credited with more than has been traditionally recognized, then it is perhaps time to broaden the traditional view of Enlightenment studies. 


\section{The Enlightenment and modernity}

As Munck in his The Enlightenment $(2000)^{1}$ has illustrated, the dividing line between the enlightened and non-enlightened is at best often vague. Hopefully no historian will wish to argue that determining the practical relationship between the intellectual elite of the Enlightenment and the 'lower orders', or those less intellectually inclined, is of no moment in our understanding of what we refer to as the Enlightenment.

If the philosophes were often motivated to overstate their role and influence, they did not do so unaided. In this respect their greatest allies were often also their greatest enemies: those conservatives who, for their own ends, wished to talk up the deist or freethinker threat to Christianity. The bogeyman of deism was frequently identified by clerics and protagonists of the faith, of both the orthodox and dissenting type, some of whom wished to create reputations for themselves and/or their sect by publicly appearing as stalwart defenders of 'true' Christian orthodoxy. The Church-in-danger cry was, however, also used as a general means of calling the faithful to order. In the process, such ardent Christians played a major role in creating a very public antichristian bogey that did not have any substantial reality. The fact that most European states and kingdoms were still confessional states - that is, with only one permitted state religion - means that religious conflict very often also had a political aspect. Thus the notion of a purely religious conflict is usually problematic, and the term politico-religious is often more appropriate. The content of such conflicts, however, could take quite different forms in response to the varying political and religious circumstances across Europe - as they did in England, France and the Italian peninsular.

In France, more so as the mid eighteenth century approached, the struggle of dissenting Catholics (Jansenists) against the orthodox Catholic Church and state was often conceived as a struggle not only for at least a limited form of religious toleration, but also against perceived Bourbon despotism. In their struggle to achieve greater religious independence from Rome, however, Jansenists in the Italian peninsular favourably contrasted absolutist secular rule with the perceived religious despotism of the Curia and the Papal States. In the case in Britain, which had already developed political parties in the late seventeenth century, it is appropriate to talk also of party-political struggle, in which the condition of the Church was still a very important issue indeed and supposed threats to the 


\section{The Enlightenment and religion}

Church were politically exploited in a very public manner. In its various forms, then, an understanding of the broad politicization of religion is central to any understanding of religious outlook and change during the Enlightenment.

If, at first sight rather strangely, defenders of the faith could talk up the threat of deism, many modern historians also seem strangely reluctant (despite compelling evidence) to accept that central to religious change in the Enlightenment was that most modern phenomenon, public opinion. In terms of the traditional philosophy of history, this refusal is, nevertheless, hardly surprising. Enlightenment studies, as is the case in most historical research, has implicitly conceived of intellectual change as a more or less exclusively topdown process. The core of my argument on intellectual change, however, is that it is rarely solely a top-down process and, on the question of religion at least, public opinion is always a major factor. Yet public opinion has usually been regarded as a modern phenomenon, of relatively less importance prior to the French Revolution. I wish to assert, therefore, that religious change in early modern Europe cannot be understood without placing public opinion at centre stage - as the case studies of France and England illustrate even though it was certainly not always an unsullied force for 'progressive' change.

In summary, my aim has been to begin illustrating the problems inherent in a history of the Enlightenment unduly based on the discourses of the enlightened elite, since in most cases their writings had little impact upon religious change and reform. Instead, historians should concentrate upon a history of the Enlightenment based more upon actual practice, upon a wider, more social-historical conception of the Enlightenment than has traditionally been the case. Above all, I will examine the role of religious opposition in generating events which brought about fundamental change in the religious culture of Western Europe. If this entails less talk about Voltaire et al., and more about other 'lesser' figures and more focus on wider social and religious change, it will certainly not mean undervaluing the philosophes. Rather it will be to understand their lives more comprehensively, to situate them properly and to appreciate the dilemmas and opportunities they confronted. Consequently, this book will offer very little focus on the writings of the philosophes, the deists and their supporters, which have already been widely reproduced, translated, compared and discussed in 


\section{The Enlightenment and modernity}

many publications. ${ }^{2}$ It is to these publications that readers unfamiliar with the writings of the philosophes should turn.

I claim no particular originality for my theoretical criticisms of modern historians. The problem of the present influencing the past and the creation of false intellectual traditions was raised and discussed some decades ago, before the advent of postmodernism one only needs to think of Quentin Skinner's 'Meaning and Understanding in the History of Ideas' (1969). ${ }^{3}$ What has not so far been attempted is to subject topics such as modernity and religion in the Enlightenment to theoretical analysis alongside a re-evaluation of the available evidence and nature of the historical record. In terms of case studies, where sufficient research data exists (as in the case of France, and partly in the case of England), I offer a new analysis of the data, and I am therefore indebted to a range of other scholars. Where relatively little data exists relevant to my arguments - most significantly in the case of Italy - I supply my own.

\section{The structure of this book}

Chapter 1 ('The myth of Enlightenment deism') discusses the reasons why the myth of a deist movement has remained so important to Enlightenment studies, even when the evidence adduced for it has been markedly insufficient. I examine the claims for a deist movement, the actual numbers of verifiable deists, the problem of defining deism and how the desire to identify the roots of and validate modernity has led to long-term distortion of historical evidence and subsequent interpretation. In Chapter 2 ('Historians, religion and the historical record') the historical record and the problems of interpreting it are brought under focus. Here I move from the distortions of historians to the inherently biased and misleading nature of the historical record itself and the role of politico-religious struggle in its creation. Historians must ask which historical reality - as provided by the historical record - they wish to choose, for competing constituencies of interest have bequeathed to us not objective history, but above all their views upon the issues of the period. Thus, the myth of the deist movement is not solely the invention of historians, but was itself first invented in the early Enlightenment with the aid of the powerful tools of politics and public opinion.

The following three chapters are case studies intended to illustrate my main arguments. That they do so in different ways is in 


\section{The Enlightenment and religion}

part a consequence of the diversity of the Enlightenment experience, which was not intellectually, geographically or chronologically even. The case study of England is the first of the case studies because, as is now well acknowledged, the Enlightenment was at its most precocious in England, decades before the height of the Enlightenment in France or that of the more restricted experience of the Italian peninsula. Discussion on England is also given first place because conditions there relate quite directly to the main arguments of the preceding chapters on the creation of the myth of deism. The subsequent chapter on the French experience focuses much less on the creation of the myth of deism than the supposed role of the philosophes, for it is above all in France that historians have identified the cutting edge of the enlightened campaign against the old regime. The final case study on the experience of the Italian states has yet a different focus, for the relatively limited Enlightenment there suffered under very different politico-religious conditions from elsewhere in Europe, yet nevertheless produced some remarkable although much neglected anticlerical writings.

In Chapter 3 ('The English deist movement: a case study in the construction of a myth') the emphasis is upon the politicization of religion and the reasoning and mechanisms by which the scare figure of deism was manufactured, dealing primarily with the period from the 1690 s to the 1730 s. I illustrate how sections of the clergy and political class were keen to talk up the existence and threat of a deist movement for their own particular ends. Most importantly, the debate further deepens the discussion on how centrally important was public opinion to the whole process of creating the historical record. The next two case studies on France and Italy, however, contain very little discussion devoted to deism and instead concentrate much more intensely on identifying the broad elements and processes of religious change.

The discussion of the French experience in Chapter 4 ('France: the revolt of democratic Christianity and the rise of public opinion') illustrates that the tiny number of philosophes - few of whom were deists - were more bystanders than activists in the major politicoreligious events and developments of the century. In fact, they can hardly be termed consistent fighters for toleration, at least as Enlightenment studies has traditionally understood that term. Again, the discussion focuses on public opinion and broad forces for change, challenging the notion of an all-embracing French 


\section{The Enlightenment and modernity}

absolutism. The parlements, Jansenists and broad public opinion achieved what the deists and philosophes never even consistently fought for: the suppression of the Jesuits, the development of a de facto toleration prior to the Revolution, and the initiation of the demands for constitutional government.

Chapter 5 ('Italy: Roman tyranny and radical Catholic opposition') is devoted to bringing to light the nature of the polemical challenge that radical Catholics - Jansenists - advanced against Roman theocracy and Church jurisdiction in the independent states of the Italian peninsula. In the practical absence of the voices of deists and philosophes, the 'tyranny' of Rome was opposed by broad Catholic forces in very forceful terms remarkably similar to those of dissenting Protestants. Even in the unusual polycentric conditions of the Italian peninsula, this chapter demonstrates how politics and religion were intertwined, and that the broad politicization of religion is really the key to understanding religious change in the Enlightenment.

The first section of the concluding Chapter 6 ('The "public sphere" and the hidden life of ideas') discusses the significance of 'misreadings'. Eighteenth-century participants and constituencies of interest could - wittingly or unwittingly - 'misread' the publications and events of the period, contributing to the origins of modern myths about the eighteenth century. The main discussion here, however, focuses on the role of public opinion in intellectual change on core Enlightenment topics such as toleration. The dominance of the top-down model of intellectual change has prevented due recognition of the role of the wider public in the formation of the idea of religious toleration. It is also asked whether it is appropriate for modern (or postmodern) historians to place modern definitions of religious toleration upon the shoulders of eighteenth-century thinkers. By doing so historians invite anachronistic comparisons with the twenty-first century. Only by broadening the scope of Enlightenment studies beyond the traditional canon can we hope to grasp and investigate the intellectual dynamic of what we have termed the Enlightenment.

The function of the Appendix is to redress the hitherto frequently misleading impression that, in Enlightenment Britain, the subject of 'natural religion' or the 'religion of nature' was the reserve of deists and other enemies of the Church. For enlightened thinkers, evidence for a rational or natural religion lay in the 


\section{The Enlightenment and religion}

qualities (especially reason and conscience) of an unchanging human nature and the frame of nature itself. As the Appendix indicates, however, the topic of the positive contribution of natural religion to Christianity was common in Enlightenment England. Of the many English Protestant works touching on this subject, I list just a few examples in order to indicate the tenor and variety of thought upon it.

\section{Notes}

1 T. Munck, The Enlightenment. A Comparative Social History 1721-1794 (London: Arnold, 2000).

2 For general surveys on the philosophes and religion see, for instance, Peter Gay, The Enlightenment. An Interpretation. Vol. 1: The Rise of Modern Paganism (London: Norton, 1995; 1st edn 1966); J. Byrne, Glory, Jest and Riddle. Religious Thought in the Enlightenment (London: SCM Press, 1996); J. Champion, The Pillars of Priestcraft Shaken (Cambridge: Cambridge University Press, 1992); G. R. Cragg, The Church and the Age of Reason 1648-1789 (London: Penguin, 1962); O. Grell and R. Porter (eds), Toleration in Enlightenment Europe (Cambridge: Cambridge University Press, 2000); I. Rivers, Reason, Grace and Sentiment. Vol. 2: Shaftesbury to Hume (Cambridge: Cambridge University Press, 2000); F. Venturi, Settecento Riformatore. Vol. 2: La Chiesa e la Repubblica dento i loro limiti (Turin: Einaudi, 1976); F. Venturi, Italy and the Enlightenment, ed. Stuart Woolf (London: Longman, 1972); B. Young, Religion and Enlightenment in Eighteenth-Century England. Theological Debate from Locke to Burke (Oxford: Clarendon Press, 1998).

3 Q. Skinner, 'Meaning and Understanding in the History of Ideas', History and Theory, 8 (1969); although I do feel that focus on his notion of illocutionary force will necessarily solve the problems faced by many historians. 